\title{
Manifestações culturais e religiosas no Norte de Minas: dando voz a foliões, peregrinos e ancestrais esquecidos
}

\author{
Cultural and religious expressions in the north of Minas Gerais: giving voice to \\ revelers, pilgrim and pilgrims and forgotten ancestors
}

Ênio José da Costa Brito*

\begin{abstract}
Resumo
No texto o autor visita quatro teses de doutorado - fruto de um Dinter entre a PUCSP e a UNIMONTES - que analisam manifestações culturais de perfil religioso no Norte de Minas. Os temas trabalhados são: Folias de Reis, Devoção à Santa Cruz, Festa de Santo Antônio e Dança no Candomblé de Angola. As teses nos relembram que a cultura e suas manifestações religiosas constituem elemento fundamental para a valorização de homens e mulheres e do seu meio, sejam quais forem as formas escolhidas para traduzir suas visões de mundo e suas demandas.
\end{abstract}

Palavras chaves: Folia de Reis, Santa Cruz, Devoção, Santo Antônio, Dança

\begin{abstract}
In this essay, the author explores four Phd thesis - elaborated under a Multi-Institutional Thesis Program between PUC-SP and UNIMONTES, which analyze religious-related cultural manifestations in the North of Minas Gerais. The subjects discussed are: 'Folias de Reis', 'Devotion to the Holy Cross' and 'Santo Antonio' celebrations and the 'Angola's Candomblé Dancing Rituals'. The works remind us that culture and its religious manifestations are key elements in men's and women's and their living environment valorization, whatever approach used to translate their worldviews and personal demands.
\end{abstract}

Keywords: Folia de Reis, Holy Cross Devotin, Santo Antônio, Dancing Rituals

\begin{abstract}
Artigo recebido em 27 de agosto de 2016 e aprovado em 15 de setembro de 2016.
* Doutor em Teologia pela Pontificia Universidade Gregoriana (1979), graduação em Teologia pela Pontificia Universidade Gregoriana (1972), graduação em Filosofia pela Faculdade Nossa Senhora Medianeira (1966), professor titular da PUC-SP, professor do Centro Universitário Assunção UNIFAl e professor do Instituto São Paulo de Estudos Superiores ITESP. País de origem: Brasil. E-mail: brbrito@uol.com.br
\end{abstract}

Horizonte, Belo Horizonte, v. 14, n. 43, p. 1093-1124, jul./set. 2016 - ISSN 2175-5841 


\section{Introdução}

Em janeiro de 2012, depois de longa negociação, o Programa de Estudos Pós-Graduados em Ciência da Religião da Pontifícia Universidade Católica de São Paulo firmou convênio com a Universidade Estadual de Montes Claros (UNIMONTES) para iniciar um Dinter ${ }^{1}$. Em 2016, com a defesa de 10 teses encerrou-se o Doutorado Interinstitucional.

Experiência enriquecedora para as Universidades envolvidas no Projeto, as pesquisas realizadas priorizaram temas locais oferecendo uma ampla visão do campo religioso do Norte de Minas e de algumas de suas práticas.

Nada mais justo do que fazer memória de parte desta contribuição dada para os estudos da religiosidade no país. Tendo participado de quatro das defesas, neste artigo partilho com os leitores considerações, observações e sugestões feitas ao longo das arguições destas teses, que têm relação com a religiosidade popular.

\section{Folias de Reis no Norte de Minas}

A primeira tese, intitulada $O$ devoto folião e a folia divina: música $e$ devoção nas folias católicas em Montes Claros (MG) - 2012-2015, de Luciano Cândido e Sarmento, deu uma contribuição significativa para o resgate, a preservação e a divulgação das nossas memórias religiosas, ao acompanhar celebrações em que estão mesclados as crenças dos colonizadores europeus e elementos da religiosidade indígena e africana, parte da herança híbrida que

\footnotetext{
1 “Doutorado Interinstitucional (Dinter) são turmas de mestrado e de doutorado conduzidas por uma instituição promotora (nacional) nas dependências de uma instituição de ensino e pesquisa receptora, localizada em regiões, no território brasileiro ou no exterior, afastadas de centros consolidados em ensino e pesquisa. As turmas estão vinculadas a programas de pós-graduação nacionais recomendados e reconhecidos com nota igual ou superior a 5. A instituição promotora é responsável por garantir o nível de qualidade das atividades de ensino e pesquisa desenvolvidas por seu programa de pós-graduação na instituição receptora". Disponível em: www.capes.gov.br/avaliaçao/projeto-minter-e-ou-dinter. Acessado em: 22/08/2016.
} 
formou o nosso povo ${ }^{2}$.

Folias, ternos de folia, companhia de reis, são muitos os termos utilizados para denominar este tipo de manifestação do catolicismo no Brasil. Difundidos predominantemente nas regiões sudeste, centro oeste e nordeste, estes grupos representam uma parcela significativa entre as variadas expressões do catolicismo em nosso país" (SARMENTO, 2016, p. 8).

Sarmento preocupa-se em oferecer aos seus leitores alguns pressupostos para que as Folias de Rei sejam bem entendidas. Elas não podem ser coarctadas no período natalino (2016, p.14)3; devem ser olhadas na sua totalidade a partir de seus elementos simbólicos, sociais, culturais e religiosos (p.140). Recomenda, ainda, "considerar todas as partes que as integram" (p.21) e compreendê-las como práticas dinâmicas. As práticas religiosas das Folias Católicas se dão em meio a transformações, tradições e idiossincrasias. Os Grupos passam por constantes ressignificações de referências simbólicas. A música deve ser compreendida como prática cultural e religiosa (p.38).

Tendo apontado estes pressupostos pontua: "neste trabalho, busca-se uma compreensão das folias como prática religiosa, considerando a mesma como uma estrutura complexa, envolvendo valores e comportamentos específicos de seus seguidores, devotos e praticantes, os foliões” (14).

Sarmento tem uma proposta clara de pesquisa, que envolve as Folias Católicas, na cidade de Montes Claros, analisadas como manifestações religiosas profundamente musicais. Tem clareza com relação aos objetivos: apresentar o universo cultural e religioso dos foliões e seus grupos de Folia (p.57) e compreender a religiosidade, cultura e música, imbricadas em situações pessoais e comunitárias de cunho religioso.

\footnotetext{
2 Tese defendida em 16/06/16 sendo a banca examinadora composta pelos professores doutores João Edênio dos Reis Valle (Orientador), Ferdinand Beki Doren, Fernando Torres Londoño, José Rocha Cavalcanti e Ênio José da Costa Brito.

${ }_{3}^{3}$ Passaremos a indicar apenas as páginas das teses.
} 
As questões que pretende responder são significativas: como explicar as semelhanças e as diferenças rituais entre as Folias de Reis? Como compreender as Folias de Reis como práticas religiosas (p.14)? O que é o Sagrado para os Foliões? (p.101). Qual a função da música, sua potencialidade na manutenção das práticas religiosas e representações devocionais? (p.25); ou como a Música, em seu espectro cultural, afeta as concepções e motivações religiosas dos grupos de Folia? (p.130).

Para dar conta do que se propunha, Sarmento revisitou vários textos escritos sobre Folias de Reis, mas principalmente mergulhou fundo no universo das Folias em Montes Claros4. Selecionou como foco central da pesquisa os grupos de Folia Estrela de Belém e Barro do Paiol, sendo o primeiro urbano e o segundo rural.

\subsection{Dos capítulos}

A tese está estruturada em quatro capítulos, Música, cultura, religião: interfaces no campo da Religiosidade Popular no Brasil; As Folias em Montes Claros: História e Devoção no Norte de Minas; Folia é cultura, Folia é Religião; e Características musicais dos Grupos observados.

No primeiro capítulo, Música, cultura, religião: interfaces no campo da religiosidade Popular no Brasil (p. 30-59), o autor abre duas discussões atuais, uma acerca da área de conhecimento autônomo das Ciências da Religião e a outra da relação entre Teologia e Ciências da Religião. A primeira envolvendo questões epistemológicas, que vêm sendo diuturnamente refletidas pela área nos últimos

\footnotetext{
${ }^{4}$ Enumero algumas das teses consultadas por Sarmento: $A$ bandeira e a máscara: estudo sobre a circulação de objetos rituais nas folias de reis de Daniel Bitter (2008) ; "Na jornada de Santos Reis: uma etnografia da folia de reis do mestre Tachico, de Wagner Neves Diniz Chaves; "As Folias de Reis de João Pinheiro: performance e identidade sertaneja no noroeste mineiro", de Ana Maria Célia da Silva Gonçalves; "Os giros do sagrado: um estudo etnográfico sobre as folias em Urucuia (MG)", de Luzimar Paulo Pereira (2009; "Entre sombras e flores: continuidades e rupturas na educação estética de devotos-artistas de santos Reis", de Marcos Antônio Soares (2006); Iconografia como processo comunicacional da Folia de Reis: o avatar das culturas subalternas", de Kátia Maria Roberto de Oliveira Kodama (2009 ; "With an open heart: folia de reis, a Brazilian spiritual journey through song", de Welson Alves Tremura (2004) e o importante estudo de Suzel Reily, "Voices of the Magi: enchanted journeys in southeast Brasil" (2002).
} 
anos. Quanto à relação problemática entre Teologia e Ciências da Religião, na expressão de Sarmento (p.31), penso ser necessário uns esclarecimentos para que a discussão não se faça em bases equivocadas. Deve-se evitar uma compreensão redutiva da Teologia e do fazer Teologia. As razões são muitas, aponto duas: não se pode negar certa fixidez no âmbito teológico, mas defini-la como ciência ainda ancorada em sua confessionalidade cristã, me parece anacrônico, uma vez que a ideia de que cabe à Teologia apenas a racionalização da fé e a sistematização dos discursos sobre Deus vendo sendo superada. O mesmo vale para uma visão apenas militante da Teologia.

Afonso Ligório, no texto que escreveu para o Compêndio de Ciência da Religião, intitulado Ciência da religião aplicada à Teologia, nos relembra: "Na prática, porém, pode-se dizer que o ponto de partida do fazer teológico é geralmente uma pergunta crítica à sua tradição de origem, que nem sempre se resolve em mera "proteção dela mesma"” (2013, p. 653). Além disso, soa estranho na atualidade manter distinções rígidas de campos disciplinares; há todo um esforço para incentivar "interrogações transversais", que convidam e facilitam o diálogo entre diversas áreas de conhecimento.

Entre as muitas afirmações sugestivas presentes no capítulo, destacamos algumas: a primeira sobre o conceito de religião. "No entanto, a predominância do pensamento eurocêntrico cristianizado teve influência marcante na construção dos significados do termo" (p. 31). Afirmação que merece ser explicitada e explorada bem mais, apontando, por exemplo, as consequências decorrentes desta visão para as experiências religiosas populares e a possibilidade de se olhar a temática numa perspectiva pós-colonial. Constata, ainda, que está ocorrendo um deslocamento nos grupos de Folias de Reis, acarretando, gradualmente, a perda do perfil religioso, levando as folias a assumirem um perfil mais cultural/folclórico. Pode-se constatar várias queixas por parte dos responsáveis neste sentido. Sarmento deixa claro que a compreensão das Folias - que espelham o catolicismo -, ajudam na percepção da sociedade e cultura de Montes Claros (p. 57). 
No conjunto, o capítulo cumpre a sua função: levar o leitor até a Folia católica e ao católico folião com sua música5. O autor observa que

a música se revela como um elemento importante e de destaque no âmbito das Folias, mas não se manifesta como um elemento isolado, ou seja, música, dança, reza, entre outros elementos idiossincráticos, não se separam, se fazendo necessário para compreensão do fenômeno, considerar todas as partes que o integram (p.27).

As Folias em Montes Claros: História e Devoção no Norte de Minas (p. 6075) é como se intitula o segundo capítulo. Nele, nele, num primeiro momento, o autor resgata dados históricos e geográficos sobre Montes Claros, tendo em vista evidenciar a história e a consolidação de grupos de Folia na cidade; em seguida, traz dados, frutos da inserção etnográfica por parte do autor no cotidiano dos foliões.

Sarmento faz memória do seu encontro com os grupos e começa a apresentar para o leitor o mundo montesclarense das folias, relembrando que foi a onda migratória ocorrida a partir da década de 1970, que trouxe as Folias para a cidade, que se industrializava e urbanizava.

O município de Montes Claros pertence à Bacia Hidrográfica do rio Verde Grande, afluente do Rio São Francisco, e está a 638 metros de altitude, com temperaturas quentes e clima seco, contando com uma população estimada em 394.350 habitantes ( IBGE 2010). A cidade é comumente citada como importante entroncamento rodoviário, ligando as regiões nordeste ao centro sul do país (p.61).

Penso ser possível ampliar as informações históricas e geográficas sobre a região, ainda mais que é do conhecimento do autor alguns textos que poderiam oferecer dados significativos sobre a região. Tenho presente as obras do antropólogo João Batista de Almeida Costa (1997), professor da Unimontes. Para ele, a identidade do norte mineiro foi forjada num contexto muito especial - o Sertão das Gerais -, tornando-a distinta da tradicional identidade mineira. Outro

\footnotetext{
${ }^{5} \mathrm{O}$ autor traz uma informação intrigante sobre a música na Folia: “O estilo paulista é predominante nas Folias de Montes Claros. Duas vozes sobrepostas, vozes de frente e vozes respostas que repetem o que foi cantado (p.58).
}

Horizonte, Belo Horizonte, v. 14, n. 43, p. 1093-1124, jul./set. 2016 - ISSN 2175-5841 
texto, este também conhecido de Sarmento, é o de Alisson Luiz de Freitas de Jesus, intitulado, No sertão da Minas: Escravidão, violência e liberdade (1830-1888). Para Jesus, a leitura da vasta documentação por ele consultada “permite repensar a proximidade entre esses escravos, libertos e homens livres; o papel que as relações afetivas tiveram no cotidiano do sertão; a violência como estratégia importante nas relações entre os agentes históricos, entre outras questões" (JESUS, 2007, p.72).

O capítulo terceiro, Folia é cultura, Folia é religião (p.76-136), apresenta uma rica etnografia respaldada por um conjunto significativo de imagens, que desvelam para o leitor a natureza, as características e as funções das Folias. Os dois grupos de Folia, Estrela de Belém e Barro do Paiol, são apresentados.

O campo foi muito generoso com Sarmento que, além de ser muito bem acolhido pelos foliões, recebeu de Seu Manoel - Mestre folião do Estrela de Belém - um presente um presente dos deuses. Vamos ao relato:

Em uma dessas conversas Seu Manoel me revelou que tinha um material guardado de filmagens da Folia a partir de 2002 até 2008. Eram dezenas de fitas de vídeo, bastante desgastadas, as filmagens feitas em uma câmera que já não funciona mais, mas que na época foi uma sensação... Ao saber das fitas, me ofereci para convertê-las em DVD, o que deixou Seu Manoel empolgado e agradecido. Para ele, esta foi uma ajuda grande importância, pois assim o material estaria mais seguro e poderia ser preservado por mais tempo. Para mim, a oportunidade de conhecer mais a fundo as experiências do Terno Estrela de Belém (p.84).

Tal presente abriu para o pesquisador a possibilidade de analisar os aspectos de transformação e de reinvenção das práticas ocorridas ao longo do tempo no Estrela de Belém. Alguns das músicas gravadas naquelas fitas foram reproduzidas num $\mathrm{CD}$ que acompanhou a dissertação.

Durante a leitura da tese, ouvi duas vezes o CD; como fruto destas audições fiz duas considerações. A primeira com relação à música nas Folias: penso que elas se valeram da musicalidade inerente ao idioma para flexionar a linguagem musical 
européia e africana e, assim, criar o que chamaria de "música das Folias". A segunda relacionada com o Lundu; são várias as referências a ele na tese: o Lundu das muié (p. 97), ele reaparece quando apresenta a estrutura da "reza". Nestas ocasiões uma questão voltava sempre: como o Lundu foi parar na Folia?

$\mathrm{Na}$ cultura popular, temos uma indissolúvel articulação do corpo, da memória e da música. Corpos populares tecem encontros sensoriais e comunitários onde quer que estejam interagindo com seus santos de devoção, provocando muitas vezes restrições por parte dos poderes constituídos religiosos e civis. A perseguição ao Lundu ilustra bem os temores e os constrangimentos das elites diante de "práticas negras" e o refazer de sua vitalidade em migrações e práticas culturais outras. Como é o caso mencionado do Lundu nas Folias.

A festa é o elemento ritualístico central para os foliões. "A festa é para o ritual, o local e o tempo em que se realiza o sagrado. Os devotos celebram os compromissos firmados com os santos de devoção e o manifestam em catarse e alegria sua fé e gratidão pelas graças recebidas” (p. 101).

Susel Reily (2002, p. 150), citada pelo autor, comenta:

O espaço ritual do catolicismo popular é, portanto, um espaço de mediação entre o humano e o divino. Ele não é nem totalmente humano nem totalmente divino, mas um espaço para a expressão da humanidade dos santos e da divindade da humanidade. Neste espaço, os seres humanos e os santos se encontram e participam de traços reciprocas de mensagens e dádivas (p.100).

Nas festas da Folia a música é elemento essencial.

Tudo é cantado, o som dos instrumentos é constante. Outros sons são utilizados, mas ao chegar dos Foliões prevalece a música ao vivo, os repentes, as brincadeiras, onde vários estilos se misturam, principalmente os de origem regional e rural. Destacam-se os guainos e catiras, as músicas sertanejas, até mesmo os hits regionais, músicas aprendidas no rádio ou na televisão (p.102). 
Na festa estão presentes os três elementos centrais do ritual das Folias: os acertos, o giro ou jornada e a reza. Os acertos ocorrem no início do processo do ritual das Folias; consiste em reuniões nas quais se determinam o percurso, o número de casas a serem visitadas, as casas escolhidas para o pouso, enfim se estabelece a duração do giro. Os giros são as visitas nas casas dos devotos. Nos giros se reforça o caráter precatório, fazem parte as visitas e o pouso.

O caráter precatório das Folias indica, nestes grupos, a sua função comunitária, onde a partir dos giros e visitas, reúnem-se os provimentos necessários para a realização da festa do santo. Os pesquisadores insistem neste ponto (Brandão, Reily e Bitter). "Para os Foliões, os donativos, sejam eles quais forem, tem o mesmo valor e o que realmente importa é a intenção de quem doa" (p. 106).

A reza, como oração diária, é um divisor de águas entre o Folião que é realmente religioso e aquele que se envolve com a folia por motivações outras. "Para os mestres, a oração é o alimento da fé e deve ser praticada todos os dias, ao acordar, antes de dormir, antes e depois das refeições. É a comunicação íntima entre o devoto e o santo" (p.120).

No capítulo quarto, Características musicais dos Grupos observados (p.138-164), a preocupação básica é de apontar as inter-relações entre música e religiosidade nas Folias. Nele, o autor quer responder sua questão central: como a música, em seu espectro cultural, afeta as concepções e motivações religiosas do grupo de Folias? ( p.138).

Como moldura do capítulo, pensei no seguinte: o mundo popular não é feito de silêncios. Ruídos do atiçar o fogo, manusear utensílios agrícolas, vozes, ritmos emitidos em pulsações corpóreas - alimentam alimentam a vida e o trabalho culturalmente acionados à cadência de seus mundos. 
A leitura aponta alguns tópicos que pedem uma explicitação maior: o canto extremamente vinculado às emoções e experiências comunitárias. $\mathrm{O}$ canto torna-se prece, no caso das Folias Natalinas, prece que celebra a dádiva divina - o nascimento de Jesus. O que no canto se realiza "misticamente", os ritos o representam concretamente. Os ritos são expressão material do canto.

Um segundo tópico: a música - primeira forma de linguagem - é movimento corporal, faz vibrar o corpo. A música estabelece a harmonia entre o invisível e o visível. Enfim as letras das músicas, que tâm forte conexão com as narrativas de infância dos evangelhos de Mateus 2,1-12 e Lucas Lc 1,1-14.

Sarmento nos relembra que o principal instrumento da Folia é a viola (p.158). No belo livro de Ivan Vilela (2013), intitulado: Cantando a própria história. Música caipira e enraizamento, temos inúmeras informações sobre este instrumento. Vilela estuda a evolução da viola desde suas origens árabes e ibéricas até os dias atuais, detalhando aspectos técnicos do instrumento, a riqueza de variações, as afinações. Nas folias observadas, a viola é utilizada com a afinação cebolão; no entanto, nas diversas folias de Montes Claros foram observadas outras afinações como vencedor, oitava, meia guitarra e rio abaixo” (p.159).

Ao acompanhar as Folias pode-se perceber a rede de valores e formas vividas pelo povo. Para o autor:

As Folias Católicas assumem um papel determinante nas práticas sociais e religiosas. Durante os rituais em Montes Claros, no Norte de Minas se estabelecem espaços e momentos sagrados, marcados por símbolos, música, movimentos e objetos que concretizam a ligação entre os devotos foliões e Deus, o Divino Espirito Santo e outros santos de devoção. A diversidade e riqueza dos elementos históricos tradicionais preservados nos rituais das folias em Montes Claros, revelam importantes traços de nossa história e de nossa identidade, mantidas pela cultura oral, preservada nos causos, rezas, músicas, ladainhas e orações. O sagrado se estabelece no ritual efêmero regido pela música dos foliões, acompanhado pelas mulheres rezadeiras, adultos, jovens e crianças, inseridos no contexto da festa, parte também sacralizada pelo ritual dirigido ao santo (p. 167). 
Luciano Sarmento, ao longo de sua pesquisa, não caiu no erro romântico de acreditar que as Folias fossem imunes a tensões sociais. Teve bem presente que quando se vai a campo, faz-se necessário ter a sensibilidade para perceber que nem todo o saber pode e deve ser dispensado sem limites, sem preâmbulos. A ciência acadêmica não tem todos os direitos, estes esbarram nos limites da ciência dos foliões.

Lembro-me de ter lido num depoimento de uma Princesa do Reinado de Nossa Senhora do Rosário que disse: "Há momentos em que, se pode, a gente se abre como couve-flor; há outros em que devemos nos fechar como uma ostra”.

Muito positivo, que "os sons do Brasil periférico" se façam presentes no âmbito universitário, como o ter dado a palavra aos representantes das duas folias, o que fez com as Folias aparecessem como um "fenômeno vivido" e não apenas como um tema de reflexão acadêmica.

A música envolve e conduz os rituais. Tocar é um ato de oração, unido num gesto único ao canto e à dança. Nas Folias, não há músicos no sentido profissionalizante do termo, e sim pessoas que desde sempre têm o direito e a liberdade de expressarem e vivenciarem a fé musicalmente, conforme a habilidade de cada um e as possibilidades de atuação estabelecidas pelo contexto ritual. A música, ou seja os sons compartilhados, é para a maioria das culturas uma maneira privilegiada de viver a comunidade. As Folias de Reis estão aí para comprovar.

\section{Devoção à Santa Cruz}

A tese de Juliana Aparecida Silva Farias Dias, intitulada Cruz de Deus, cruz do povo. Concepções e práticas de devoção à cruz na Caminhada Santa Cruz, Norte de Minas Gerais, é a segunda tese que visitaremos'. Nela a autora "buscou verificar as concepções e práticas de devoção na "Caminhada Santa Cruz" nas

\footnotetext{
${ }^{6}$ Tese defendida no dia 19/03/16, participaram da banca os professores doutores João Edenio dos Reis Valle (Orientador); Fernando Torres Londoño; Martinho Contini; Robson Medeiros Alves e Ênio José da Costa Brito.
} 
comunidades rurais de Lages, Machados e Santa Rita de Santa Cruz, situadas no norte de Minas Gerais" (p. 6).

Tema fascinante, pois a devoção é centenária e revela as potencialidades da religiosidade popular, a sua relativa autonomia, a sua capacidade de resistência e de dar sentido à vida. No entanto, os desafios não foram pequenos, nas palavras da autora:

O depoimento dos devotos foi um caminho para tentar construir um registro da história da Caminhada, mas um grande desafio de fazer de um colcha de retalhos um todo coerente. Inicialmente tencionava trabalhar através de fontes escritas, mas ficou constatado a inexistência de um registro, sendo necessário recorrer aos indivíduos e suas memórias no trabalhoso, porém delicioso exercício de escuta,paciente e atenciosa, no intuito de não perder nada em nenhum "causo" e partir das narrativas, da memória, interpretar como começou e se transformou ao longo do tempo (p.70).

\subsection{Dos capítulos}

O primeiro capítulo, Religiosidade popular e Devoção à cruz: Abordagem histórica (p. 14-36), oferece dados que auxiliam o leitor a perceber a estrutura desta devoção centenária. "Segundo alguns relatos, a caminhada teve início há aproximadamente 100 anos, tendo sido interrompida com a morte de um dos pioneiros na prática de subir o monte para rezar aos pés da cruz: o senhor Sebastião Cardoso" ( p. 74).

A devoção popular à Santa Cruz tão presente no território nacional foi introduzida pelos colonizadores portugueses, no entanto no Brasil ganhou as suas especificidades. "Contrariando as decisões tridentinas no interior da Igreja do Brasil se desenvolveu uma religião sincrética” (p. 27). Esta observação confirma ter sido muito lenta a recepção do Concílio de Trento (1545-1563) pela Igreja brasileira. $\mathrm{O}$ aparelhamento institucional da Igreja Católica foi bastante lento no Brasil colonial; exemplificando: o Bispado da Bahia foi criado em 1551 e por mais de 100 anos permaneceu o único no território nacional. Na América espanhola, a 
dinâmica foi diferente, a pensar que em 1585 o México realizava o $3^{\circ}$ Concilio Provincial visando adaptar as leis existentes aos decretos tridentinos.

Relembro que a data de 03 de maio (dia da Santa Cruz) recorda a recuperação da cruz sob o imperador Heráclio e sua entrega, pelo ano de 629, a Zacarias, Patriarca de Jerusalém. Alguns anos antes, os persas tinham roubado a cruz. A festa foi acolhida nas diversas liturgias ocidentais. O Oriente, no entanto, manteve apenas a solenidade da Exaltação da Santa Cruz, ocasião em que, como lembrança da descoberta do sagrado Madeiro, ele era mostrado solenemente ao povo.

Juliana Dias, ao apresentar ao leitor a história desta devoção desde os primórdios do cristianismo, aponta as características da mística da cruz vivenciada pela religiosidade popular. Mística traduzida no cotidiano em gestos concretos, como nas romarias, na construção de capelas e em algumas práticas penitenciais.

Fazer caminho caminhando (p. 37-66) é o título do segundo capítulo, de perfil etnográfico, fruto de uma pesquisa participante, que descreve a "Caminhada Santa Cruz" caracterizada pela devoção à cruz. Cinco cruzeiros são visitados na zona rural norte-mineira. Um conjunto de fotos acompanha a etnografia.

Esta devoção conserva traços de um catolicismo tradicional, praticado por 300 anos na Colônia, sendo marginalizado no Império e na República para a introdução de um catolicismo renovado. "A devoção à cruz, centenária conforme dados obtidos, teria nascido no âmbito privado, hoje faz parte da vivência religiosa de devotos de três comunidades rurais norte mineiras. Nasceu, conforme os relatos, das subidas ao monte "para pedir chuva"' ( p. 36).

Alguns temas ganham visibilidade no capítulo: tema da gestualidade, da fartura e o tema relacionado com os foguetes. Este último, se presta para se pensar numa "espiritualidade do olhar". O devoto acompanha com devoção e respeito os foguetes que sobem ao céu, como se levassem seus desejos e preces, 
O "Cruzeiro do Redelvino" fica no alto do morro de subida íngreme, difícil, com muitos buracos, pedras e plantas. [Os devotos ] entoavam cantos e orações diversas: o Oficio de Nossa Senhora7, o Credo, músicas à Santa Cruz. Os foguetes indicavam o início da caminhada e a chegada no cruzeiro, aliás a cada cruzeiro um foguetório" ( p. 43).

Teoricamente, o capítulo se sustenta em dois conceitos, mística e tradição, este último voltará a embasar o capitulo quarto da tese.

No terceiro capítulo, A caminhada da Santa Cruz no tempo e na história (p. 67-103), descreve os procedimentos metodológicos, visando compreender a longa duração da devoção; examina sua construção e reconstrução e delineia o imaginário da cruz, que permeia as práticas devocionais. Volta-se, ainda, para a representação que os atuais participantes da "Caminhada" fazem da cruz, em estreita relação com a cultura do cotidiano e com as mudanças no campo religioso.

No impresso distribuído para os devotos acompanharem a festa, em 2015, lê-se:

Se a festa é fonte de bem que se renova a cada ano, o tempo ordinário é ignorado para viver outro tempo; o tempo que lhes garante proteção permanente contra o mal e esta mentalidade se forma com valores que enraízam-se no interesse de garantir a permanência e o bem-estar de coisas exteriores consideradas necessárias e básicas: a roça, a família, a saúde, a reprodução dos animais (p. 95) .

O subtítulo do ponto 3.4, o caminho da cruz: os cruzeiros, aponta um topus literário/religioso da maior importância: vida/via. A vida como uma caminhada.

Os cruzeiros são enfeitados, pedras se amontoam nos pés da cruz.

Há muitas pedras, depois de falar com o senhor Zé de Marinho, entendi que estavam lá há muitos anos, e como ele disse ninguém retira de lá, por causa do peso. Quando falávamos sobre isso, deixou entender, que ficou admirado de tamannho esforço que deve ter feito quem as carregou. De

\footnotetext{
7 Oficio de Nossa Senhora, prática devocional muito difundida no país (p.89). O Oficio é cantado, rezado diariamente (p.100). No Instituto Teológico São Paulo (ITESP) tive oportunidade de participar de uma banca de Mestrado intitulada: "Os grandes louvores da Virgem Mãe de Deus: um estudo das práticas do oficio da Imaculada Conceição na cidade de São Paulo." O autor Valdiran Ferreira loccalizou na periferia de São Paulo muitas famílias nordestinas, que ainda rezam o Oficio.
}

Horizonte, Belo Horizonte, v. 14, n. 43, p. 1093-1124, jul./set. 2016 - ISSN 2175-5841 
fato tem muitas pedras nos cruzeiros, especialmente no cruzeiro, especialmente no cruzeiro do senhor Redelvino (p.96).

Entre os temas marcantes do capítulo, podemos apontar: a tradição oral, presente nos atos devocionais e na catequese, que nos convidam a refletir sobre a memória e subjetividade dos devotos. Ganha destaque um segundo tema, o da fé popular. O texto trouxe elementos que permitem traçar o perfil da fé popular e compreendê-la um pouco mais, pois no geral não é bem compreendida. A fé popular não é abstrata, é sincrética, ela se materializa nos gestos e nas práticas. "A fé sincrética salienta que o sopro do Espirito já esteja agindo nas demais tradições culturais antes, contra ou mesmo apesar do contato com as comunidades cristãs" (SOARES, 2010a, p.38. Ver também SOARES, 2010b).

Para Dias, "as práticas populares transitam entre o místico e a alegria da festa e dos rojões, às comidas abundantes ao encontro com parentes e amigos" (p.103). (Ver VALLE, 2006).

O capitulo quarto intitula-se, Fim da caminhada (p. 104-118) no qual a autora retoma, brevemente, os pontos fulcrais da pesquisa. A figura do devoto é a personagem central, "o devoto do Bom Jesus é um cristão cheio de piedade e compaixão, que sofre, espera, aceita o sofrimento e se compadece do sofrimento do outro" (p. 105). (Ver ESPIN, 2000). Entre as inúmeras devoções relembra a do Bom Jesus da Cana Verde, devoção antiquíssima, presente não só no Paraná, mas também em Minas, na cidade de Tabuleiro, cuja festa é celerada em 14 de setembro ${ }^{8}$.

Um aspecto, a ser destacado na Caminhada Santa Cruz realizada pelos devotos, é o caráter de exorcismo da oração recitada aos pés do cruzeiro, que funde o imaginário da cruz com a defesa contra o demônio. Ana de Fátima reproduziu o texto utilizado na Caminhada de 2015:

8 Para uma visão mais ampla da devoção ao Bom Jesus da Cana Verde no Paraná, ver Lino, 2016.

Horizonte, Belo Horizonte, v. 14, n. 43, p. 1093-1124, jul./set. 2016 - ISSN 2175-5841 
Aguentarei o golpe da morte. Que o campo Jesus achaste Os inimigos da Santa Cruz, Encontrarás e lhe dirás: Foge e arreda Satanás! Parte de mim tu não terás. Porque no dia da Santa Cruz Cem vezes me ajoelhei, Cem vezes me persignei, Cem vezes o chão beijei, Cem vezes te reneguei e renego, Cem ave-marias rezei, Cem vezes me levantei. (Autor Desconhecido) (p.110).

\section{Em sua pesquisa, Dias localizou}

uma fórmula do século XVIII na região das Minas. Meynardo Rocha Carvalho chamou de 'Ladainha de Santa Cruz', que era recitada, utilizando-se de bagos de milho durante a reza, com todos ao redor de uma mesa, passando de mão em mão repetindo: Jesus, Maria, José, minha alma Vossa é. E rezavam a ladainha: Arreda e afasta satanás, / Porque essas almas não são suas. / Ao dia de Santa Cruz. / Direi mil vezes Jesus (p. 110)9.

Para Dias, a festa da Santa Cruz tem uma herança portuguesa, mas é importante ter presente que quem a levou adiante no Brasil foram os escravizados. Em São Paulo, por exemplo: a festa da Santa Cruz foi celebrada pelos negros do Bexiga até a década de 1940, com batuques e danças. Através deste festejo, buscavam manifestar a sua cultura e afirmar a sua presença, pois o bairro, gradualmente, vinha sendo ocupado pelos italianos (calabreses). Acabou saindo do Bairro, hoje é celebrada em Carapicuíba (SP) (Ver BORGES, 2013, p. 131-138).

Os festejos de Santa Cruz, antes de serem realizados nas ruas centrais do Bexiga , no século XIX eram realizados com leilão de prendas, música e dança, em torno da cruz preta erguida no Largo do Piques ( atual Praça da Bandeira)... Coube ao sapateiro José da "Ponte" da "Ponte" porque cuidava e residia nas proximidades da Ponte do Pique a iniciativa de erguer o cruzeiro, após ter retirado a cruz do rio Anhangabaú, na altura da baixada do Pique ( BORGES, 2013, p. 134-135) ${ }^{10}$.

\footnotetext{
${ }_{9}^{9}$ Outra referência importante localizada pela autora encontra-se na Revista Lusitana, no 38 de 1943, no artigo intitulado "Textos Religiosos do Fol-kore Madeirense, o autor Eduardo Pestana resgata uma coletânea de orações recitadas na llha de Madeira. Os textos exaltam o Bom Jesus e a Santa Cruz (p.110).

${ }^{10}$ Camara Cascudo no Dicionário de Folclore afirma que a festa da Santa Cruz traz muito do índio e dos missionários.
}

Horizonte, Belo Horizonte, v. 14, n. 43, p. 1093-1124, jul./set. 2016 - ISSN 2175-5841 
Para a autora a tese descortinou:

a origem da caminhada e as motivações, e o que impulsionou também o seu retorno no século XXI. A festa existe há mais de um século e foi mantida por conta de uma consciência identitária: na visão dos devotos é uma tradição a ser preservada como memória de uma experiência religiosa, que eles tem dos antepassados, que "pediam" e "recebiam" cada vez que iam ao cruzeiro (p. 121) ${ }^{11}$.

\section{No sertão do São Francisco festa de Santo Antônio}

Comentamos a seguir a tese de Denilson Meireles Barbosa intitulada Heranças de fé no Sertão do São Francisco: devotos e romeiros na Tradicional festa de Santo Antônio em Serra das Araras, MG. ${ }^{12}$

Ao terminar a leitura, a pergunta que me ocorreu foi: o que o Denilson Barbosa, como cientista da Religião, propôs com sua tese? Penso que sua proposta foi a de: reconhecer de fato a religião/religiosidade dos devotos/as de Santo Antônio e examinar a sua lógica, isto é, identificar a religiosidade subjacente às práticas culturais-religiosas. Examinar práticas religiosas populares de longa duração é um desafio fascinante para os cientistas da Religião. Barbosa, ao atentar para as particularidades do contexto histórico do distrito de Serra das Araras, pode perceber a tradição oral enquanto expressão cultural dos próprios moradores e visitantes, que empreendem múltiplos sentidos às narrativas, dotando-as de diferentes representações e apropriações culturais. E é a partir desse amplo panorama que as criatividades dos anônimos sujeitos (re)constroem as festividades em torno do santo, na medida em que mesclam os universos "sacro" e "profano", as temporalidades "passado" e "presente" e as especificidades "individuais" e “coletivas” (p. 23).

\footnotetext{
${ }^{11}$ Cinco apêndices compõem a tese: Termo livre de Consentimento, Questionário para os Devotos, Carta de Cessão, Perfil dos Participantes da pesquisa e a rica Transcrição das Entrevistas.

12 Tese defendida em 20 de junho de 2016; participaram da Banca os professores (as) doutores Maria José Fontelas Rosado Nunes (Orientadora), Antonio Alvimar Souza, Fernando Torres Londoño e Ênio José da Costa Brito
} 
Inúmeras são as consequências desta opção: livrar o cientista da Religião de uma apologia ingênua das práticas religiosas populares; levar a sério as conexões interculturais e inter-religiosas, pois, elas são vivências cotidianas dos devotos/as; perceber que estas práticas poderiam consistir numa bem-vinda terapêutica para certas escleroses dogmáticas das religiões em geral. Por isto nos relembra que a festa toma lugar do legalismo (litúrgico) (p. 62). E ainda identificar como a fé nessas borderland (no sertão) se concretiza, se traduz, uma vez que não existe fé em estado puro, ela só se mostra na prática. Este último ponto, me fez lembrar de uma passagem de um importante documento do Vaticano II, que afirma: "a fé destina-se a ajudar a humanidade (podemos dizer as pessoas) a encontrar soluções mais humanas a seus problemas históricos" (Gaudium et Spes, n 11). Estas consequências convidam o leitor a entender praticamente como sinôminos: o sincrético, o histórico, o traduzido e o concretizado.

Entende-se, então, a preocupação do autor de oferecer alguns pressupostos epistemológicos para se estudar a religião/religiosidade (p. 29), especialmente frente a categorias inadequadas, que não captam as especificidades das práticas religiosas em geral e em particular das práticas religiosas populares (p. 35).

Entre estes pressupostos pode-se apontar: evitar modelos dicotômicos (p. 32); categorias generalizantes; ilustro este pressuposto com as palavras do autor: "as generalizações tornam-se assim um instrumento limitado no auxílio da interpretação dos ritos, das práticas religiosas e do universo simbólico constituído a partir das devoções"(p. 35). Faz-se necessário, também, ter presentes a autonomia e o poder de recriação das populações interioranas (p. 36) e manter a perspectiva crítica, procurar avançar na criação de categorias analíticas (ponto de suma importante). 


\subsection{Análise da estrutura}

Na Introdução, deixa claro a importância do tema: não há pesquisa. "Faltam pesquisas sobre a vida religiosa sertaneja” (p. 16); como também a hipótese e o objetivo com aos quais trabalha: "Nossas hipóteses se fundam em supor inicialmente que, na medida em que as gerações seguintes assumem as práticas devocionais na festa de Santo Antônio, a manutenção da mesma está garantida dentro das especificidades regionais" (p. 23); e "nosso objetivo se constitui na verificação e interpretação das práticas tradicionais de saber religioso, herdadas pelas gerações seguintes no âmbito das festas de Santo Antônio em Serra das Araras no município de Chapada Gaúcha no norte de Minas Gerais” (p. 23).

A festa de Santo Antônio, "surgiu na localidade da Serra das Araras, povoado que se tornou distrito em 1917 e em 2011 recebeu o primeiro santuário da região (p. 44). Barbosa pretende produzir e sistematizar o conhecimento sobre as práticas tradicionais mantidas por diversas gerações, como forma de manutenção do patrimônio cultural apreendido continuamente a partir da observação e pela repetição.

O capítulo primeiro, Religião e Religiosidade no Sertão (p. 26-51), comenta, primeiramente, as dificuldades de se pesquisar religião popular no Brasil e contextualiza a religião/religiosidade na América Colonial sob a influência da Península Ibérica. Em seguida, analisa diversas práticas católicas no sertão, mostrando como "os sertanejos sabem tornar os espaços em limites sagrados. Objetos diversos são ressignificados enquanto símbolos que são capazes de representar novos significados a partir do culto que pode ser prestado aos mesmos" (p. 46).

Para o autor, 
a cultura religiosa de um povo, portanto, além de epresentar uma tradição pelas configurações históricas e antropológicas existentes, pode também representar a herança de uma memória coletiva capaz de influenciar nas formas de adesão de outras gerações, às expressões culturais de terminados grupos familiares ou não" (p. 47).

No segundo capítulo, Religiosidade e festa popular: devoções reinventadas (p. 52-83), o autor levanta dados significativos (sua palma), mas os explora pouco sob o aspecto analítico-hermenêutico (sua cruz). Exemplificando, no ponto 2.2 Festa e festejar um espírito devocional (p.58-61) deparamos com informações importantes (espalhadas pelo texto), que pedem para serem articuladas e analisadas. Retomo, sinteticamente, as informações deste tópico: a festa constitui um evento importante da vida sertaneja: é um espaço de devoção e sacralização das práticas de fé; possibilita a partilha, a integração e a coesão da população e coroando esta "mandala da festa popular" nos diz que "a festa é espaço de resistência"(p. 62). No ponto 2.3, Santo Antônio um santo sertanejo nas quebradas do sertão, temos ricas informações, como as diversas virtudes do santo; o fato do santo ter escolhido o topo do morro para morada, lugar onde a estátua tinha sido encontrada ${ }^{13}$.

A romaria de Santo Antônio tornou-se tão popular e sagrada pelo retorno do santo ao topo da serra. A não aceitação de mudança de lugar o tornou um santo poderoso no sertão do São Francisco. Para Bráz,(1977, p.439) "Santo Antônio zombou dos devotos interesseiros e dos camaristas", pois exatamente quando se construía uma igreja na principal praça da vila para onde havia sido trazido, lugar no qual a Câmara municipal havia denominado por lei, de praça Santo Antônio em sua hora santa. Ele foge de volta à serra . "A Igreja em construção foi desapropriada e demolida [...]. Para que Igreja, se Santo Antônio não quis a cidade? ( p. 66) ${ }^{14}$.

O que leva Barbosa comentar: "Santo Antônio em um tempo mítico fundou a sacralidade da serra (monte sagrado), tornando possível a integração do homem com a natureza divina" (p. 69).

\footnotetext{
${ }^{13} \mathrm{Em}$ outra passagem, o autor comenta: "Santo Antônio desafiou estar no ponto mais elevado, atravessou rios, cruzou o sertão, escapou dos seus 'capturadores', rebelou-se contra a vontade alheia e ressignificou o espaço sagrado da montanha, escolhendo por vontade própria, o seu altar natural" (p. 67)

14 O autor nos relembra que os propagadores da devoção a Santo Antônio foram os jesuítas, Vieira era um admirador do santo (p. 6364).
}

Horizonte, Belo Horizonte, v. 14, n. 43, p. 1093-1124, jul./set. 2016 - ISSN 2175-5841 
A religiosidade popular sertaneja transformou-se num fenômeno social que engloba inúmeras dimensões e explica a manutenção da romaria pela repetição, pelo compromisso moral, pela memória familiar e pelas práticas cristalizadas na memória das famílias (todas são justificativas válidas ), mas penso que caberia mais uma - a meu ver importante - para enriquecer nosso olhar sobre as manifestações da religiosidade popular, sinalizada pelo autor ao comentar a fala de uma devota, mas que não é inserida no rol apresentado. "Na fala sustentada pela devota, percebe-se o quanto a prática anual da romaria parece possibilitar a renovação dos laços de afetividade com o Santo, renovação do ciclo de vida através do encontro com o taumaturgo" (p. 78, grifo meu). Falar da presença da afetividade nas práticas devocionais desvela um aspecto profundo da mística popular, que passa despercebida de muitos estudiosos ${ }^{15}$.

No capitulo final, Romeiros e devotos: Guardiões da memória religiosa (p. 74-131), propõe: realizar uma análise detalhada da festa, com ênfase nos saberes e fazeres das rezadeiras e rezadeiros; analisar o turismo e a dimensão cultural da festa/religiosidade e identificar e caracterizar o perfil imagético da festa e dos romeiros. Proposta que é cumprida meticulosamente.

O grande mérito foi de trazer à tona registros inéditos das expressões religiosas do religioso no Sertão. Tais manifestações experienciadas de diversas formas, como por exemplo a sacralização do Rio Catarina (p. 103), podem ser um raro meio para o entendimento da identidade desse povo.

Alguns pontos chamam atenção do leitor: a apresentação e as razões dadas para relacionar o inventário dos bens que se tornaram patrimônio cultural religioso das famílias sertanejas. Descreve, com precisão cirúrgica, as relações da Igreja institucional com as manifestações religiosas populares. A ação institucional da Igreja coarcta a fé do povo. Pensando nestas relações, a Igreja pode e deve acolher o desafio de: “devolver às sociedades tradicionais e não tradicionais, presentes no

${ }^{15}$ As mulheres lideram as romarias (p.79), traçar o perfil delas ajudaria o leitor a perceber a sua efetividade. 
Brasil e em qualquer outro país, o tempo e as condições favoráveis a fim de que, caminhando com seu próprio ritmo e índole, tracem seu destino (religioso) rumo à plenitude de Sentido" (SOARES, 2006, p. 1).

O que tem ocorrido é uma luta por parte dos devotos - que transformaram Santo Antônio num santo sertanejo -, para manter suas práticas devocionais. Resistência baseada num tripé: tradição, herança e memória. Tradição, que baliza a identidade do grupo, consagrando um direito adquirido e transmitido por gerações; herança que não pode ser negada, mas deve ser preservada com suas especificidades, como seu modo próprio de vivenciar a fé e celebrar a devoção que, passando por estruturas familiares, se estendem no tempo, e memória que contribuiu e contribui para a compreensão do processo histórico das rupturas ou transgressões possíveis no espaço devocional sertanejo.

Denilson Barbosa revela ser um pesquisador carismático pela facilidade com que "se faz sertanejo", pelo cuidado com que acolhe a fala dos devotos e mapeia suas riquezas materiais e imateriais. A tese, ao nos apresentar um autêntico mapa da Festa de Santo Antônio, no Distrito da Serra das Araras, oferece-nos a possibilidade de refletir a respeito da visão de mundo dos devotos/as, fundamentada em tradições cristãs, africanas e indígenas, organizada a partir de símbolos, ainda presentes no Brasil profundo.

\section{Dança e religião}

Girando em uma roça banto: a dança como elementos constitutivo do Candomblé Angola em Montes Claros/MG é o título da bela tese de Fernanda de Souza Cardoso ${ }^{16}$.

Começo apresentando breves, mas significativos, realces da tese: o diálogo tecido com autores africanos ao longo do texto - Vansina, Hampâté Bâ, James

\footnotetext{
${ }^{16}$ Tese defendida no dia 17 de junho de 2016, sendo membros da banca examinadora as professoras examinadoras Maria José Fontelas Nunes (Orientadora ); Elisangela Chaves; Larissa Michelle Lara; Teresinha Bernardo e o professor Ênio José da Costa Brito.
} 
Sweet, Miller, Altuna entre outros - dá à tese uma densidade específica; impressiona o leitor, como a autora se apropriou dos autores estudados, extraindo deles o que de melhor tinham com relação ao seu tema; a tese combina bem etnografia e reflexão, isto é, não só realiza uma consistente etnografia como reflete a partir dela, dando um perfil analítico ao texto; utiliza muito bem as notas de rodapé, uma ou outra poderia até ser inserida no texto; por fim, a tese mostra o trabalho de uma pesquisadora detalhista, precisa e consistente.

Ilustro com um exemplo: comentando a questão do "dançar bem” afirma: "não é o domínio da técnica que mais importa nesta experiência religiosa, mas sim o fato de o adepto buscar compreender os significados dos gestos daquilo que está em cena mas que também encena” (p. 101).

\subsection{Dos passos}

No Passo 1 de uma coreografia, intitulado Dança e religião (p. 25-57), o capítulo oferece ao leitor uma arqueologia da dança, priorizando sua ligação/ relação com a dimensão sagrada, com os grupo e os indivíduos (p. 23). A elaboração desta arqueologia permite à autora afirmar entre outras coisas que: as danças de uma maneira ou outra participam do cotidiano de muitas das ações diárias das sociedades (p. 56); nas comunidades onde a dança está inserida, ela contribui com a "sobrevivência plena" (p. 56) e a dança foi essência indispensável para ocorrência dos mitos-ritos (p. 57). Esta última afirmação é a hipótese com a qual a autora trabalha.

Assim, compreendemos que não houve sequer um tempo em não houvesse dança; nem mesmo nos momentos em que esta foi reprimida, não sucumbiu aos ditames que imperavam. Em algum reduto, lá estava ela, reiterando sua força. Neste sentido, já aqui aparece uma ligeira aproximação com a hipótese deste estudo: em algum outro tempo-espaço a dança também foi essencial indispensável para ocorrência de muitos ritos (p. 56-57). 
O Passo 1 ficou devendo aos futuros leitores algumas informações. Quando trata da dança nos diversos períodos, tem possibilidade de ilustrar com imagens; só para ficar com um exemplo: quando comenta sobre as pinturas nas cavernas, como as pinturas de $\operatorname{Knossos}$ (p. 44) ${ }^{17}$, relacionadas com danças, pode ilustrar com imagens; ao tecer considerações sobre a "famosa dança de Davi", finaliza comentando que as danças eram executadas nos próprios templos e faz uma menção à Festa do Tabernáculo, cabe uma breve explicação desta festa (p. 40); pode, ainda, ampliar uma preciosa afirmação (p. 54): a dança não é integrada à celebração litúrgica. Afirmação que ecoará, quando comentar a dança na Idade Média, neste período a dança foi proibida nos templos.

Duas relações têm uma presença marcante no capítulo: dança/cultura e dança/sagrado. Outro tema recorrente é o da dimensão paideica/pedagógica da dança (p.41), muitas são as passagens: dança atividade que forma o cidadão (p. 43); dança educadora das emoções (p. 90) e a relação entre dança e ensino/ensinamento (p. 96; 105). Na conclusão, reitera esta dimensão ao afirmar: “desta forma parece haver um processo pedagógico ali [dança] instituído” (p. 131). Para Leda Martins (2002, p. 83) para afirmar que "os ritos cumprem, assim, uma função pedagógica paradigmática, exemplar, como modelo e índice da mudança e deslocamento" (p. 99).

Para a autora, "como constructo, a dança se apresenta incorporando as necessidades, os pensamentos específicos de cada tempo. E como esta dança se sustentou e se sustenta em alguns espaços religiosos visto que para alguns deles ela é onipresente" (p. 55).

No Passo 2 de uma Coreografia - Candomblé Angola: "os ancestrais esquecidos" ganham vozes e dançam (p. 58-91) -, a tese realiza uma aproximação gradual da rica e pouco conhecida tradição banto (p. 84), com uma

\footnotetext{
17 No palácio de Knossos (1600 a C) descoberto pelo arqueólogo inglês Arthur Evans aparecem algumas pinturas que retratam um costume cretense de fazer adolescentes dançarem diante de um touro.
} 
intencionalidade bem definida “dar voz aos 'ancestrais esquecidos', buscando não mais um ‘não lugar' mas garantindo a eles espaços que lhes são devidos” (p. 59).

Para alcançar este objetivo: destaca a "cosmologia banto" e suas práticas religiosas, em seguida, a "cosmologia angola” e a presença marcante do caboclo. Finaliza, relembrando que a tradição cultural angola foi seletivamente reconstruída no Brasil, no entanto essas reconstruções/ressignificações nos remetem às matrizes africanas.

Dá passos firmes, ao levantar "a hipótese da anterioridade dos cultos banto brasileiros sobre o culto jêje-nagô dos orixás no Brasil” (p. 89) e a construção da nagocracia, em especial na Bahia. Vale a pena lembrar que Reginaldo Lucilene, na sua pesquisa intitulada Os Rosários dos angolas: Irmandades de africanos e crioulos na Bahia setecentista, discute amplamente estas questões. Para ela, Nina Rodrigues foi influenciado pelos escritos de M. d'Avezac sobre a multiplicidade das raças humanas que hierarquizava os grupos humanos. Os bantos ocupavam o lugar inferior entre os próprios negros. Recebeu influência também de estudantes brasileiros retornados da África, onde internalizaram a teoria da superioridade iorubá, criada por uma elite africana.

O estereótipo criado com relação aos bantos era de serem dóceis, com enorme capacidade de adaptação, mas de uma extrema pobreza mítica estereótipos mantidos nos escritos de Arthur Ramos, Roger Bastide e Edison Carneiro. "Nestes autores, aos povos bantos permeáveis e dóceis diante da cultura ocidental, apenas restou a magia e o sincretismo, enquanto os iorubás foram capazes de criar uma verdadeira religião” (LUCILENE, 2011, p. 284-285).

Três passagens fortemente interligadas nos dão um pouco da dinâmica interna do Passo 2. São elas: “a cultura africana não é algo abstrata”, que possa ser separada da vida (p. 72); “a Nação Angola pode revelar valores, costumes e mundividências, mesmo que ressignificados remetam a uma origem africana”(p. 89) e "cada Terreiro é um universo particularmente criado e recriado" (p. 91). Tais 
afirmações apontam para a cosmovisão africana e sua potencialidade de recriar condições de vida nos mais adversos contextos. Lucilene, numa passagem do livro Os Rosários dos Angolas. Irmandades de africanos e crioulos na Bahia setecentista, exemplifica esta potencialidade:

os africanos continuaram no Brasil um processo de síntese cultural que começou combinando criativamente elementos culturais que os ajudaram em seu novo lar ( novo mundo). Eles escolheram símbolos transculturais que fizeram a mediação entre o seu mundo antigo e o mundo novo. Os reis e as rainhas nas irmandades serviram como mediadores; também como mediadores em um sentido africano, entre o mundo dos vivos e o mundo dos mortos. (LUCILENE, 2011, p. 227).

No Passo 3 de uma coreografia - A dança no Candomblé de Angola: o corpo que Dança e que ora (p. 92-110) - a autora volta-se para a dança e sua presença no Candomblé de Angola, dança vista "como um dos constitutivos do Candomblé". O movimento realizado no Passo 3 está estruturado em torno de três tópicos: essência da dança, suas características e suas funções no Candomblé. Dinâmica fecunda, que dá a Cardoso a oportunidade de fazer afirmações marcantes como estas: "sem dança você não faz Candomblé (p. 97); "a dança é um elemento central (p. 106) e ainda acolher a afirmação de Redinha (2009, p. 331): "a dança, para o povo africano é uma predestinação, um mistério, uma ânsia de ritmo supremo, desempenhando importante papel em todos os setores da vida dos Africanos (p. 93).

Esta onipresença da dança na vida das comunidades africanas é relembrada por Olaudah Equiano, preso em 1745, quando tinha apenas 11 anos por traficantes de escravos em sua aldeia Igbo, na Nigéria. Ele tem presentes na sua autobiografia as festas realizadas na sua aldeia quando toda a comunidade dançava, chegando a afirmar: "Somos quase uma nação de dançarinos, músicos e poetas" (VASSA, 2002, p. 7). 
Cardoso nos relembra, também, ser, "o tambor o mais religioso dos instrumentos" (p.95). Me perguntei porque? Penso que pelo fato do tambor reunir em si os reinos vegetal, animal e mineral, e os vínculos das divindades - orixás, inquices, e voduns -, com as forças da natureza viva. Na cosmogonia de culturas afro, corpos concebidos como componentes da natureza se relacionam com o universo das divindades e ancestralidades (ANTONACCI, 2014, p. 139-150).

Lembrei-me de uma poesia de Admilson Pereira de Almeida, intitulada Três Tambores Sagrados, analisada por Maria José Somerlate Barbosa no artigo Dicionário de Forquilhas: a poesia de Edmilson Pereira de Almeida.

O poema "Três Tambores Sagrados", publicado no livro Árvore dos Arturos (1988), é uma amostra de como Pereira examina a diversidade cultural afro-mineira. Nesse texto, ele discute o significado dos tambores (Santana, Santaninha e Jeremia) no ritual do Candomble, considerandoos como símbolos da tradição, das vozes dos ancestrais e do espaço sagrado. Os tambores registram momentos de alegria, celebração, mas também apontam para a necessidade de "tomar sentido" e de se agarrar ao significado da tradição, que se reinventa e se conserva viva ${ }^{18}$.

Barbosa chama a atenção para o refrão: “o Santana, o santaninha e o ... / São três os tambores sagrados”. Ela comenta a omissão do nome do terceiro tambor no refrão, que recebe diversos nomes nas comunidades afro-mineira. Seu nome mais comum é Jeremia, como lemos acima. Na poesia é substituído por um tempo em mutação - num outro verso lê-se: “ São dois / o terceiro é o tempo.”

Numa outra passagem lemos: "Os africanos tomavam parte em quase todo tipo de festa na Colônia e no Império” (p. 96). Os africanos não tomavam apenas parte, mas se apropriaram de muitas festas. Mary del Priore, em Festas e utopias no período colonial, explora bem este dado. No capitulo, intitulado A cultura preta na Festa, mostra como diversos grupos de mulheres e homens mulatos e negros, alguns com extraordinária capacidade de acumulação, utilizavam a festa católica branca para criar "um espaço para exercer as tradições da sua terra mesmo que

\footnotetext{
${ }^{18}$ Disponível em:.www-letras.ufmg.br/literafro. Acessado em: 02/08/16. Para uma visão da comunidade dos Arturos, ver. Gomes; Pereira (2000).
}

Horizonte, Belo Horizonte, v. 14, n. 43, p. 1093-1124, jul./set. 2016 - ISSN 2175-5841 
integradas, maquiadas ou já adaptadas à realidade colonial (PRIORE, 1995, p. 87). O próprio discurso oficial mostra que a presença na festa desses grupos de mulatos e negros era fruto de negociações; expõe a imagem que a cultura negra fazia de si e das outras e "revela, mais ainda, que ambos os grupos, explorados e escravizados, souberam encontrar brechas de resistência, sobrevivência comum e mesmo da integração" (PRIORE, 1995, p. 79).

Ao caracterizar a "Dança em transe, síntese final do processo religioso" (p. 97; p. 105), a autora acolhe uma afirmação de Bárbara (2002) que diz: “A Dança em Transe" vai além da pura gestualidade, inserindo-se no movimento do universo e recuperando energia.

As danças de transe expressam a fé das filhas e filhos de santo que se deixam tomar e ser conduzidos pelas divindades, cada um com um fluxo e a qualidade do movimento do dono da cabeça ao qual corresponde, a fim de reequilibrar as forças cósmicas para si mesmos e para a comunidade (p.107).

Aafirmação aponta para toda a potencialidade religiosa da dança. Entendese então o que subjaz ao comentário de Kiosô sobre a beleza da dança, que ultrapassa a dimensão estética : "O inquice é movimento. Se não tem movimento não tem dança. Então por isso, as danças. E daí vem as belezas, além de tudo isso, né” (p. 100).

No passo 4 de uma coreografia, intulado Composição coreográfica: girando em uma Roça Banto (p. 111-127), consciente ou inconscientemente, Cardoso estabelece um link com "Antes de tudo....." um texto testemunho com o qual abre a tese e desvela para o leitor o que significou no âmbito existencial, a feitura da mesma. "Anteriormente à escrita dos capítulos desta tese, necessários para um adequação aos moldes acadêmicos, tive uma intensa necessidade, talvez nada acadêmica, de dizer algumas coisas àqueles que um dia optarem por ler estes escritos (p. 13). 
Ambos os textos estão escritos na primeira pessoa. O ponto alto, quando foi convidada a dançar "para sacerdote, alguns de seus filhos e filhas de santo e convidados” (p. 118). Digno de nota, a força presente nas festas de estabelecer vínculos (p. 123), com os membros da casa, com os visitantes e com as entidades ${ }^{19}$. Finalizo com as palavras da autora:

Neste desfecho podemos dizer que no candomblé, por meio da experiência do corpo em movimento, sensações são provocadas, cores, gestos e sons se misturam e promovem celebração, corporificação, oferenda. Os filhos e filhas de santo da "Roça" concebem que a dança relembra os ancestrais; permite o privilégio da vinda do inquice. A dança, como ato comemorativo, promove alegria e 'prepara o corpo' para o transe, para esse encontro com o "sagrado", unindo físico e espiritual". Dinamiza os rituais públicos fazendo emanar o ngunzu e, finalmente, dançar é um forma diferenciada de oração ( p.131-132).

\section{Conclusão}

As quatro teses analisadas convidam o leitor a refletir sobre a extraordinária capacidade das manifestações populares de se preservarem no tempo e conferirem identidades aos que delas participam ${ }^{20}$.

Sabemos que a preservação de valores culturais caracteriza-se, fortemente, como uma peça de resistência atual a uma tendência inquestionável da época contemporânea de plastificar as culturas. A valorização do regional, do universo local, em contraposição à onda avassaladora de uma globalização onipresente é vital para a afirmação de identidades especificas e da sensação de pertencimento, que garante às pessoas o orgulho de suas raízes e a referência de seus lugares.

As pesquisas desvelam um pouco da sabedoria presente na vida de devotos, foliões, peregrinos e participantes das mais diversas manifestações culturais e religiosas que, mesmo em situações adversas do dia-a-dia, encontram razões para

\footnotetext{
19 Uma sugestão dada por mim, foi que a autora elaborasse um pequeno glossário no qual retoma as inúmeras palavras banto presentes na tese, já explicadas em notas de rodapé.

${ }^{20}$ Brevemente as teses estarão disponíveis na Biblioteca Virtual da PUCSP.
} 
celebrarem a vida em comunidade e manifestarem sua confiança no incerto amanhã.

Convidam homens e mulheres, mergulhados no corre-corre das grandes aglomerações urbanas, a acompanharem os passos lentos daqueles que celebram seus santos padroeiros e suas entidades. Desafiam descobrirem na oralidade de suas narrativas, na gestualidade de seus passos e de suas danças um sentido vital.

No seu conjunto, as teses apresentam um pouco da rica vivência religiosa e festiva do Norte de Minas, vivências pouco conhecidas da elite montesclarense, mas presentes nas comunidades rurais.

Temos presente que não é fácil para um Brasil moderno e urbano, construído sobre o asfalto e o plástico e as grandes concentrações urbanas, compreender e valorizar, ainda que parcimoniosamente, a riqueza e a criatividade

de saberes e fazeres ancestrais, com sua cultura e religiosidade, construídas e preservadas ao longo do tempo, mesmo com inúmeras dificuldades.

Em suas páginas, as pesquisas comentadas nos mostram que a cultura, popular ao invés de silenciar-se, construiu um "Brasil por dentro", na diuturna articulação de uma escrita de cores, de batidas percussivas, de gestos, de danças e de rezas dos grupos populares e afro-brasileiros.

\section{REFERÊNCIAS}

ANTONACCI, Maria Antonieta. Memórias ancoradas em corpos negros. $1^{\text {a }}$ Edição. São Paulo: EDUC, 2014.

BÁRBARA, Rosamaria. A dança das Aibás: dança, corpo e cotidiano das mulheres de candomblé. 2002. Tese (Doutorado), Universidade de São Paulo, São Paulo, 2002.

BORGES, Rosangela Ferreira. Axé! Madona Achiropita. 2.ed. São Carlos (SP): Pedro e João Editores, 2013 [2001].

BRAZ, Brasiliano. São Francisco nos caminhos da história. São Francisco, 1977 
ESPIN, Orlando. A fé do povo. Reflexões teológicas sobre o catolicismo popular. São Paulo: Paulinas, 2000.

COSTA, João Batista. Cultura Sertaneja: a conjugação de lógicas diferenciadas. In: SANTOS, Gilmar Ribeiro dos (Org.). Trabalhos, cultura e sociedade no Norte/Nordeste de Minas: considerações a partir das ciências sociais. Montes Claros: Beste Comunicação e Marketing,1997, p. 77- 95.

GOMES, Núbia Pereira de Magalhães; PEREIRA, Edimilson de Almeida. Negras Raízes Mineiras. Os Arturos. Belo Horiznte: Mazza Edições, 2000.

JESUS, Alisson Luiz de Freitas de Jesus. No sertão da Minas: Escravidão, violência e liberdade (1830-1888). São Paulo: Annablume: Belo Horizonte: FAPEMIG, 2007.

LINO, Anderson. Aproximações culturais e conflitos sociais em torno da imagem do Bom Jesus da Cana Verde: entre o passado ibérico e as disputas no Brasil. 2016 (Tese) - Doutorado em Ciências Sociais, Pontifícia Universidade Católica de São Paulo, São Paulo, 2016.

LUCILENE, Reginaldo. Os Rosários dos Angolas. Irmandades de africanos e crioulos na Bahia setecentista. São Paulo: Alameda, 2011.

MARTINS, Leda. Performances do tempo espiralar. In: RAVETTI, Graciela;ABEX, Márcia (Orgs.).Performance, exilio, fronteiras: errâncias territoriais e textuais. Belo Horizonte: Departamento de Letras Românicas; Faculdade de Letras/UFMG: Poslit, 2002.

PESTANA, Eduardo. Textos Religiosos do Fol-klore Madeirense. In: Revista Lusitana, no 38.1943 .

PRIORE, Mary Del. Festas e utopias no período colonial. São Paulo: Brasiliense,1994.

SOARES, Afonso Maria Ligório. In: USARSKI, Frank; PASSOS, João Décio.(Orgs.). Compêndio de Ciência da Religião. São Paulo: Paulinas,2013,

SOARES,Afonso Maria Ligório. Sincretismo e teologia interconfessional. In: CiberteologiaRevista de Teologia \& Cultura, Ano VI, n.27, Jan/Fev, 2010a, p.32-52

SOARES,Afonso Maria Ligório. Valor teológico do sincretismo numa perspectiva de teologia pluralista. In: Cibertologia, Ano VI, n.30, Jul/Ago, 2010b, p.29-40.

SOARES,Afonso Maria Ligório. A inculturação do símbolo cristão nas comunidades de tradição afro: reflexões provocadas pela leitura de J.L. Segundo. In: Ciberteologia- Revista de Teologia \& Cultura, Ano II, Jan/Fev, 2006, p.1-14.

REDINHA, José. Etnias e culturas de Angola. Coimbra: Associação das universidades de Língua Portuguesa, 2009, p. 331. 
REILY,Suzel. “Voices of the Magi: enchanted journeys in southeast Brasil”. Chicago: University, 2002.

VALLE, Edênio. Santuários, romarias e discipulado cristão. Horizonte, Belo Horizonte, v. 4, n.8, p. 31-48, jun. 2006.

VILELA, Ivan. Cantando a própria história. Música caipira e enraizamento. São Paulo: EDUSP, 2013.

VASSA,G. Las viajes de Equiano. Havana: Ediciones Huracán, 2002. 